to offer must always be given until the individual patient's particular need is fully met. This does not mean offering a simple and uncritical acquiescence in response to every and any irrational proposition. But it means a full understanding of what lies behind a patient's attitude or a colleague's request for consultation or specialist advice. It means receiving any situation and meeting it both wisely and kindly. It does not rule out the giving of a firm negative when that is required. Service to patients may take many forms-not all of them the ones traditionally understood.

The man in the laboratory who thinks that a different specimen might yield the clue to the diagnosis, and who takes the trouble to see that he receives it, is also performing a service to a patient. So is the medical officer of health serving patients when he tracks down the source of an infection and cuts it out ; or when he pesters his local authority with such diligence that the councillors at last provide the health visitors he requires. So is the medical student who risks his chief's impatience by insisting on his answering all the questions asked by the worried patient. So is the investigator who works after normal hours at publishing an important observation or at keeping himself up to date. So is the family doctor who reads the medical journals and attends postgraduate courses of instruction. The reported advances of medical science are numerous, and not all the claims are well founded. Keeping up with them and yet retaining a sense of critical appraisal is also a service to patients -often a very hard service to give. Taking trouble to write a letter, make a phone call, give a word of explanation, or simply be a good listener-all these may be services that patients desperately need and whose giving can be inconvenient to a busy doctor. But if we fail our patients in such matters we fail to be good sound doctors. And only good sound doctors are any use to patients. Only good sound doctors, moreover, can make the right stands against ignorance and arrogance wherever they are found. Such resolution, when it is needed and well judged, is also a service to patients ; but no doctor will come anywhere near to offering it effectively unless he knows absolutely within himself that he does it for a patient-in some circumstances for a patient whose name he does not know but of whose need he is acutely aware.

The age-old needs of patients persist. New needs in new forms emerge. We.dare not forget the old needs or be unwilling to understand the new ones even if the mental and physical efforts required prove tiresome and exacting.

This talk about the need for complete self-offering by doctors is not mere sentimentality. I believe that it is hard reality and the very foundation of the life and work of a doctor. I believe that we must accept it as an absolute requirement-first, because nothing less is any good to our patients ; and, second, because nothing else will give us either grace or the strength to go on.

\section{Conclusion}

In short, I believe that all the present professional disillusionment and disenchantment, despite its complex causation, is largely capable of being dispersed by doctors themselves by their making a resolve to understand and stick to our traditional professional virtues. By so doing we may hope to be widely recognized as good sound doctors ; and if we are so recognized we shall gain or regain public esteem, and many present diffculties will melt away. It seems to me that the three things that matter are: that we rejoice in being firmly bound one to another by our professional training and experiences; that we cultivate the grace of good will and good humour, and even a sense of fun, and never lose hold of this under any trials ; and that we devote our whole life and work to the service of our patients, keeping nothing back that we know how to offer. Patients' needs, however demanding, must always be compassionately received, because the only reason for our being doctors is that we have the will and the power to serve. There is no other way to happiness and fulfilment. But this one is sure.

\section{REFERENCES}

${ }^{1}$ Powell, J. Enoch, A New Look at Medicine and Politics, p. 16. London, Pitman Medical. 1966.

2 Bruce Fraser, British Medical fournal, 1968, 2, 553.

\title{
Asymptomatic Bacteriuria in Girl Entrants to Dundee Primary Schools
}

\author{
D. C. L. SAVAGE,* M.B., M.R.C.P., D.C.H.; MARGARET I. WILSON, $†$ M.SC. \\ E. M. ROSS, $\ddagger$ M.B., D.C.H. ; W. M. FEE, $\S$ V.R.D., M.B., D.P.H.
}

British Medical fournal, 1969, 3, 75-80

Cummary : During the statutory medical examination on $\checkmark$ entrance to primary school 9435 -year-old girls were screened for asymptomatic bacteriuria. A prevalence of $2 \cdot 1 \%$ was found. None of the 20 children with asymptomatic bacteriuria was recognized by the parents as having a urinary infection, though 14 of them had symptoms of lower urinary tract infection. In 16 of the children with bacteriuria either the intravenous pyelogram or the micturating cystogram was abnormal. In 12 the height and weight were below the 25th percentile, and in this group the most severe radiological changes were found.

Though the significance of asymptomatic bacteriuria is unknown, these results confirm that in this age group it is often associated with a urinary tract abnormality.

\section{Introduction}

Urinary infection-detected during screening programmes is generally referred to as asymptomatic bacteriuria. It is known, however, that though some persons with asymptomatic bacteriuria may be genuinely asymptomatic, others when carefully questioned admit symptoms of lower urinary tract infection (Kunin, 1966).

Asymptomatic bacteriuria in healthy adult populations is well recognized, and its prevalence has been proved by a number of observers (Miall et al., 1962 ; Freedman et al., 1965). There

* Lecturer in Child Health, University of Dundee.

t Lecturer in Bacteriology, University of Dundee.

F Registrar in Paediatrics, Royal Infirmary, Dundee.

$\$$ Depute Medical Officer of Health, City of Dundee. 
is, however, only one such survey in a population of healthy schoolchildren-the extensive and continuing programme of Kunin et al. (1964). They have shown that the overall prevalence rate of bacteriuria in schoolgirls is probably over $1.2 \%$, whereas in schoolboys it is much lower, of the order of $0.03 \%$. As the prognosis of asymptomatic bacteriuria in childhood is uncertain, and its association with renal infection and the development of chronic pyelonephritis is still unknown, further surveys and research into these problems are required.

In the present survey boys were not screened because of their extremely low rate of urinary infection, and among the girls only the 5-year-old children were chosen for examination. This age group was selected because Kunin et al. (1964) had noted that the rate of infection in their youngest girls-those of 6 to 7 years-was twice as high as in the older children, and they suggested that the younger age groups might be more profitably investigated in future surveys. Furthermore, it was administratively convenient ; for at this time, on entrance to primary schools, children are examined by the school health service and the opportunity would therefore arise for the collection of urine.

The immediate aims of this study were to test the feasibility of collecting large numbers of uncontaminated urine specimens from young girls during school medical examinations and to determine the prevalence of asymptomatic bacteriuria.

\section{Material and Method}

Study Area.-The City and Royal Burgh of Dundee, the third largest city in Scotland, is situated on the northern shores of the Firth of Tay. The population of about 182,000 consists largely of native-born Scots. The main industries are jute, light engineering, and preserve manufacturing.

Study Population.-The study took place between April 1967 and April 1968. All local authority primary schools with adequate medical and sanitary accommodation were included (29), but others with adequate facilities (16) did not participate. This meant that about 1,000 5-year-old girls from an annual intake of about 1,500 were available for examination.

Presentation of Programme.-Examination of the urine of school entrants is not yet routine. Nevertheless, since it can be held to form an essential part of any medical examination, parental permission was not obtained; but as most school entrants are accompanied by their mothers, the opportunity was taken to tell them of the test and the reasons for it. All medical and teaching staff involved knew of the health and research aspects of this study. General practitioners in the city were contacted before the survey began and were told when any patient was suspected of having a urinary infection.

\section{Urine Collections}

The equipment was simple to use, easily transported, and inexpensive. The urine was collected as a midstream specimen; there had been no previous cleansing of the external genitals, nor were the labia spread. The specimen was collected in a disposable sterile aluminium bowl under the supervision of the mother or nurse, and was then poured into a disposable sterile polyethylene container, sealed with a tight-fitting cap, and immediately placed in an insulated box maintained at about $4^{\circ} \mathrm{C}$. This was a standard portable blood-transfusion box, holding a container filled with water which had been frozen overnight. During the period of two to three hours while the box was opened 20 to 30 times to be filled with small containers of warm urine the temperature inside the box did not rise above $5^{\circ} \mathrm{C}$. At this temperature bacterial growth does not occur readily (Winberg, 1967). The urine was transported back to the laboratory within three hours of collection.
Up to 40 specimens were collected in a morning, the total being limited only by the number of children examined.

\section{Bacteriological Methods}

On arrival at the laboratory the specimens of urine were transferred from the insulated box to a refrigerator maintained at $6^{\circ} \mathrm{C}$. They were examined within one hour.

The urine was cultured by the method described by Bradley et al. (1967). This is a quick and efficient semiquantitative screening method for bacteriuria. The specimen of urine was mixed thoroughly by shaking, and a commercially prepared sterile cotton-wool swab, mounted on a wooden stick whose tip was a standard $1 \mathrm{~cm}$. length, was immersed in the urine. The charged swab was freed from excess fluid by draining on the inside of the urine container. The swab was then rubbed over the surface of a dried MacConkey agar plate in such a way that each of four parallel lines of inoculum was streaked four times with the swab. The swab was not rotated during the plating process. The plate was incubated at $37^{\circ} \mathrm{C}$. overnight. A pure or nearly pure and confluent or semiconfluent growth was regarded as a positive culture. Plates which showed no growth, slight growth, or mixed growth were considered not significant. Cloudy urine was examined for pus cells and organisms. Any child with a positive urine culture by this screening method had further urine specimens examined.

These urine specimens were examined by the plating-out method used for colony counts in the diagnostic laboratory (Urquhart and Gould, 1965). Horse blood agar and MacConkey agar plates were seeded with a standard loopful of urine (about $0.01 \mathrm{ml}$.). Well-shaken but uncentrifuged urine samples were examined and the bacterial colony count was expressed as the number of viable organisms per $\mathrm{ml}$. after the plates had been incubated at $37^{\circ} \mathrm{C}$. overnight.

In this study a finding of 100,000 or more viable bacteria per ml. of urine on at least three consecutive occasions was regarded as evidence of infection.

\section{Urological Investigations}

The parents of children thought to have a urinary infection were asked to bring their child to the paediatric ward, where a second midstream specimen of urine was collected under the supervision of a nurse. If this also contained significant bacteriuria the child was seen in the outpatient department, where a further specimen of urine was obtained. Immediate microscopical examination of this specimen usually showed bacilli and sometimes pus cells. The child was later admitted for further investigation. Intravenous pyelography initially did not include tomograms of the kidneys, but later these were done for better illustration of any scarring of the renal cortex. During the micturating cystogram there was no screening, and three films were taken. The first followed bladder-filling, the second after 20 to 30 minutes' delay with push back into the catheter, which was connected to a reservoir, and the third was a micturating film. Initially only those children with radiological abnormalities underwent cystoscopy, but this has now been extended to all children with infection.

\section{Results}

\section{Participation}

Out of the 45 State primary schools $29(66 \%)$ took part in this survey. Urine collected from 943 children (89\%) out of the 1,051 enrolled in these 29 schools. It was the intention to examine only the 5-year-old entrants, but about 20 older 
children who had recently moved to Dundee were inadvertently included. Out of this small group one child (Case 15) was found to have a urinary infection, and she has been included in this report.

\section{Screening Level of Significant Bacteriuria}

Initially all children whose urine specimens had any bacterial growth were recalled for further specimens to be examined, so that the level of bacteriuria that required investigation under these field conditions could be determined. When about 400 children had been examined it was clear that the collections were satisfactory enough to exclude all children with less than semiconfluent growth from their specimens of urine. The figures for the initial 14 schools, comprising a total of 432 children, are given in Table I. In the first urine specimens

TABLE I.-Urine Culture in 432 Children to Determine the Level of Significant Bacteriuria under Field Conditions

Examined by method described by Bradley et al. (1967)

\begin{tabular}{|c|c|c|}
\hline & & 1st Specimen \\
\hline 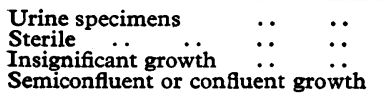 & $\begin{array}{l}\ldots \\
\cdots \\
\cdots\end{array}$ & $\begin{array}{l}432(100 \%) \\
312\} 95 \cdot 4 \% \\
70\} \\
20(9)(4 \cdot 6 \%)\end{array}$ \\
\hline
\end{tabular}

Examined by Standard Diagnostic Method for Colony Counts as described by Urquhart

\begin{tabular}{|c|c|c|c|}
\hline & & 2nd Specimen & 3rd Specimen \\
\hline $\begin{array}{l}\text { Urine specimens } \\
\text { Sterile } \\
<10,000 \text { colonies } / \mathrm{ml} . *\end{array}$ & $\begin{array}{l}\because \\
\ddot{*} \\
\ddot{*}\end{array}$ & $\begin{array}{l}90+ \\
59 \\
18 \\
3 \\
10(9)\end{array}$ & $\begin{array}{l}23 \\
14 \\
9(9)\end{array}$ \\
\hline
\end{tabular}

* These counts are approximate values.

$\dagger$ This figure includes all the children with any bacterial growth in the first urine specimen.

9 children with urinary infection.

$412(95.4 \%)$ were either sterile or contained insignificant growth. Twenty $(4.6 \%)$ yielded a semiconfluent or confluent growth. Ninety children were recalled; these comprised the 20 with semiconfluent or confluent growth and also those whose urine cultures showed insignificant growth. Of the 90 second specimens 77 were either sterile or contained fewer than 10,000 viable bacteria per $\mathrm{ml}$. of urine. There were 31 children whose second specimens had some bacterial growth, but only 23 of these were recalled; the remaining eight were regarded as free of infection, having fewer than 10,000 viable bacteria per ml. of urine in the first and second specimens, with either a mixed culture or a different organism in the two specimens. Of the 23 children recalled for a third time, nine had urine cultures with 100,000 colonies per ml., while in the remainder the urine specimens were sterile.

Among these 432 children $9(2 \cdot 1 \%)$ had a urinary infection by our criteria. These children all had at least semiconfluent growth in their first specimen, and, as no child with an initially lower bacterial growth was subsequently found in three consecutive specimens to have evidence of infection, it was decided to recall in the future only those whose urine specimens had semiconfluent or confluent growth.

\section{Prevalence of Infection}

In screening the 943 children the initial urine specimens in $906(96 \cdot 1 \%)$ were sterile or contained insignificant growth. The urine cultures in 37 children $(3.9 \%)$ had a semiconfluent or confluent growth, and $20(48.6 \%)$ of them were confirmed as having a urinary infection. For the whole group of 943 children the prevalence of urinary infection was $2 \cdot 1 \%$.

\section{History and Symptoms in Children with Infection}

The symptoms of urinary infection in those children with persistent bacteriuria and the $x$-ray findings are detailed in Table II. In 19 of the 20 children with urinary infection the mother stated that the child's general health was good, but in fact on further inquiry only three were without symptoms which could be attributed to a lower urinary tract infection. Table III summarizes these symptoms. Nine children $(45 \%)$ had never been dry, day or night ; $11(55 \%)$ had frequent nocturnal enuresis; and a further six wet their beds occasionally. Ten children $(50 \%)$ wet their pants at least once a week, in many cases on most days, and three others had occasional daytime wetting. The most frequent symptom was considerable urgency or frequency of micturition, one or both of these being present in $16(80 \%)$ of the children. Three of the children had frequent fevers of indeterminate origin, which may have been associated with their underlying urinary

TABLE II.-Individual Findings in 20 Children with Asymptomatic Bacteriuria

\begin{tabular}{|c|c|c|c|c|c|c|c|c|c|c|}
\hline \multirow{3}{*}{$\begin{array}{l}\text { Case } \\
\text { No. }\end{array}$} & \multicolumn{5}{|c|}{ Symptoms of infection } & \multirow{3}{*}{ Intravenous Pyelogram } & \multirow{3}{*}{ Micturating Cystogram } & \multirow{3}{*}{ Cystoscopy } & \multirow{2}{*}{\multicolumn{2}{|c|}{ Stature Percentile }} \\
\hline & \multicolumn{2}{|c|}{ Enuresis } & \multirow{2}{*}{ Urgency } & \multirow{2}{*}{ Frequency } & \multirow{2}{*}{$\begin{array}{c}\text { Unex- } \\
\text { plained } \\
\text { Fevers }\end{array}$} & & & & & \\
\hline & Day & Night & & & & & & & Height & Weight \\
\hline 1 & $5 / 7$ & $5 / 7$ & + & + & + & Left renal pelvis and & Reflux left kidney & Not done & $<3$ & 3 \\
\hline 2 & $7 / 7$ & $6 / 7$ & + & + & - & Right duplex kidney & N.A.D. S.T. urethra - & Normal & $<3$ & $<3$ \\
\hline $\begin{array}{l}3 * \\
4^{*}\end{array}$ & $\begin{array}{l}1 / 7 \\
3 / 7\end{array}$ & $\begin{array}{l}2 / 7 \\
7 / 7\end{array}$ & $\stackrel{+}{+}$ & $\stackrel{+}{+}$ & $\bar{t}$ & $\begin{array}{l}\text { and ureter } \\
\text { Dilated right ureter } \\
\text { Bilateral pyelonephritis. } \\
\text { Dilated ureters }\end{array}$ & $\begin{array}{l}\text { N.A.D. } \\
\text { Reflux left kidney. Bladder } \\
T \text { and } S\end{array}$ & $\begin{array}{l}\text { Not done } \\
\text { Distal urethral stenosis }\end{array}$ & $\begin{array}{r}>50 \\
<3\end{array}$ & $\begin{array}{l}>75 \\
<3\end{array}$ \\
\hline 5 & 一 & - & - & - & - & $\begin{array}{l}\text { Dilated ureters } \\
\text { N.A.D. }\end{array}$ & Reflux right ureter. Bladder & Not done & 3 & 3 \\
\hline $\begin{array}{l}6 \\
7 \\
8 \\
9\end{array}$ & $\begin{array}{l}\text { Occ. } \\
\text { Occ. } \\
7 / 7 \\
7 / 7\end{array}$ & $\begin{array}{l}\text { Occ. } \\
\text { Occ. } \\
7 / 7 \\
3 / 7\end{array}$ & $\begin{array}{l}+ \\
+ \\
+ \\
+\end{array}$ & $\begin{array}{l}+ \\
+ \\
+ \\
+\end{array}$ & $\bar{z}$ & $\begin{array}{l}\text { N.A.D. } \\
\text { N.A.D. } \\
\text { N.A.D. } \\
\text { Dilated ureters }\end{array}$ & $\begin{array}{l}\text { T.A.D. T. urethra } \\
\text { Bladder T } \\
\text { Bladder T. S.T. urethra } \\
\text { Bladder T. and S. S.T. } \\
\text { urethra }\end{array}$ & $\begin{array}{l}\text { Not done } \\
\text { Not done } \\
\text { Distal urethral stenosis } \\
\text { Distal urethral stenosis }\end{array}$ & $\begin{array}{l}<10 \\
>50 \\
<10 \\
<3\end{array}$ & $\begin{array}{l}<10 \\
>97 \\
<10 \\
<10\end{array}$ \\
\hline $\begin{array}{l}10 \\
11 \\
12 \\
13 * \\
14\end{array}$ & $\frac{\overline{7}}{3 / 7}$ & $\begin{array}{l}\text { Occ. } \\
\text { Occ. } \\
\text { Occ. } \\
\text { Occ. }\end{array}$ & $\begin{array}{r}+ \\
+ \\
+ \\
+\end{array}$ & $\begin{array}{l}\dot{+} \\
\pm \\
\pm \\
-\end{array}$ & $\begin{array}{l}\bar{z} \\
\bar{z}\end{array}$ & $\begin{array}{l}\text { N.A.D. } \\
\text { Right duplex kidney } \\
\text { N.A.D. } \\
\text { N.A.D. } \\
\text { N.A.D. }\end{array}$ & $\begin{array}{l}\text { N.A.D. S.T. urethra } \\
\text { Reflux right ureter } \\
\text { N.A.D. } \\
\text { Bladder T } \\
\text { Bilateral reflux to kidneys. } \\
\text { Bladder T }\end{array}$ & $\begin{array}{l}\text { Not done } \\
\text { Distal urethral stenosis } \\
\text { Not done } \\
\text { Not done } \\
\text { Distal urethral stenosis }\end{array}$ & $\begin{array}{r}>50 \\
<3 \\
<25 \\
<50 \\
10\end{array}$ & $\begin{array}{l}>75 \\
<3 \\
<50 \\
<50 \\
<25\end{array}$ \\
\hline $\begin{array}{l}15 \\
16 \\
17 *\end{array}$ & 二 & $\frac{7 / 7}{3 / 7}$ & 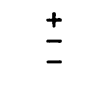 & $\bar{z}$ & $\bar{z}$ & $\begin{array}{l}\text { N.A.D. } \\
\text { N.A.D. } \\
\text { Left pyelonephritis. }\end{array}$ & $\begin{array}{l}\text { N.A.D. } \\
\text { Bladder T. S.T. urethra } \\
\text { Reflux left kidney }\end{array}$ & $\begin{array}{l}\text { Not done } \\
\text { Distal urethral stenosis } \\
\text { Not done }\end{array}$ & $\begin{array}{l}>50 \\
10 \\
<50\end{array}$ & $\begin{array}{l}>50 \\
<25 \\
<25\end{array}$ \\
\hline $\begin{array}{l}18 \\
19\end{array}$ & $\begin{array}{l}7 / 7 \\
3 / 7\end{array}$ & $\begin{array}{l}7 / 7 \\
7 / 7\end{array}$ & $\stackrel{+}{+}$ & $\stackrel{+}{+}$ & $\overline{-}$ & $\begin{array}{l}\text { N.A.D. } \\
\text { N.A.D. }\end{array}$ & $\begin{array}{l}\text { Bladder T. S.T. urethra } \\
\text { Bilateral reflux to kidneys. } \\
\text { Bladder T and S }\end{array}$ & $\begin{array}{l}\text { Distal urethral stenosis } \\
\text { Distal urethral stenosis }\end{array}$ & $\begin{array}{l}>25 \\
<25\end{array}$ & $\begin{array}{l}>25 \\
<25\end{array}$ \\
\hline $20 *$ & $3 / 7$ & $3 / 7$ & + & + & + & $\begin{array}{l}\text { Bilateral pyelonephritis. } \\
\text { Dilated ureters }\end{array}$ & Bilateral reflux to kidneys & Normal & $<3$ & 3 \\
\hline
\end{tabular}

S.T. = Spinning top. $T=$ Trabeculation. $S=$ Sacculation. Occ. = Occasional (less frequently than once a week).

* Past history of ur:nary infection. 
infection. No child had dysuria. Even if nocturnal enuresis is excluded, $14(70 \%)$ of the children had symptoms which are recognized as being frequently associated with lower urinary tract infection. Five children had a past history of urinary infection.

TABLE III.-Urinary Symptoms in 20 Children with Asymptomatic

\begin{tabular}{|c|c|c|c|}
\hline Symptom & No. & Symptom & No. \\
\hline $\begin{array}{l}\text { Health other than good } \\
\text { Past history of urinary infection } \\
\text { Never been dry day or night }\end{array}$ & $\begin{array}{r}1 \\
5 \\
9\end{array}$ & $\begin{array}{l}\text { Urgency of micturition } \\
\text { Frequency of micturition } \\
\text { Unexplained fevers } \quad . .\end{array}$ & $\begin{array}{l}\cdots \\
\because\end{array}$ \\
\hline $\begin{array}{lll}\text { Nocturnal enuresis } & \ldots & \ldots \\
\text { Diurnal enuresis } & \ldots & \end{array}$ & $\begin{array}{l}11 \\
10\end{array}$ & Dysuria $\quad \ldots$ & $\therefore$ \\
\hline
\end{tabular}

\section{Social Class}

Social class was determined from the data given by the Registrar General. This classification uses the father's occupation to place the family. One child was in social class II, one was in social class III, and the remainder were in social class IV or V.

\section{Clinical Examination}

All the children appeared well cared for, and general examination was in most cases normal. The one exception (Case 20) was listless and unwell. None of the children was found to have any coexistent disease. The blood pressure was normal in all cases. In no instance was the bladder palpably enlarged after micturition. A few children had evidence of a mild vulvitis.

\section{Height and Weight}

During the survey many of the children with bacteriuria were found to be of small stature. On the Tanner and Whitehouse growth charts seven children were on or below the 3rd percentile for height and six for weight. Twelve children (60\%) were below the 25 th percentile for both height and weight.

As there may have been a significant difference in stature between the Dundee children and those children whose heights and weights were used by Tanner and Whitehouse, a percentile chart for the Dundee girls was calculated from the heights and weights of over 800 5-6-year-old girls examined by the school health service during 1967. The mean height of these Dundee children was $1.8 \mathrm{~cm} .(0.75$ in.) less and the mean weight 0.45 $\mathrm{kg}$. (1 lb.) greater than the comparable age group on the Tanner and Whitehouse charts. In effect the heights and weights at each percentile were very similar to those of Tanner and Whitehouse, so that most of the children with bacteriuria were still below the 25th percentile for height and weight when compared with their Dundee peers.

A control group was obtained by taking the children in the survey register listed on either side of those found to have bacteriuria: the seven children (see below) with possible acute urinary infection were similarly compared with these two groups. As the ages of these three groups of children were not exactly comparable the height and weight for each child was corrected for age by subtracting it from the mean height or weight of the $8005-6$-year-old Dundee schoolgirls. These findings are shown in the Chart. The mean difference in height from normal of the control group was plus $0.09 \mathrm{~cm}$. $(0.04$ in.), while that of the children with asymptomatic bacteriuria was minus $4 \cdot 76 \mathrm{~cm}$. $(1 \cdot 87 \mathrm{in}$.). This is a significant difference $(P<0.005)$. The mean difference in weight from normal of the control group was plus $0.64 \mathrm{~kg}$. $(1.4 \mathrm{lb}$.) as compared with minus $2 \cdot 04 \mathrm{~kg}$. $(4.5 \mathrm{lb}$.) for the children with asymptomatic bacteriuria. This again is significant $(P<0.005)$.
No difference was noted in height or weight between the control group and the children with possible acute urinary infection.

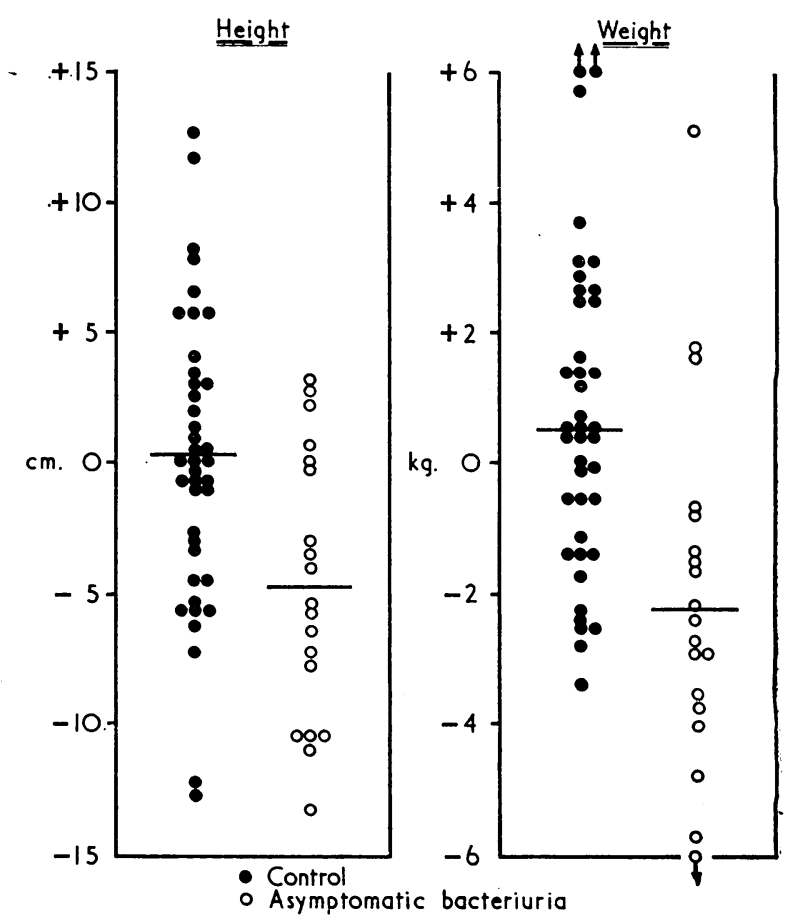

Height and weight of controls and children with asymptomatic bacteriuria expressed as the difference from the mean of 5-year-old Dundee schoolgirls.

\section{Pyuria and Bacteriuria}

At the first outpatient attendance a fresh unspun midstream. specimen was examined microscopically in a Fuchs-Rosenthal counting-chamber. In all cases the urine was cloudy. Proteinuria was absent. Pyuria, defined as more than 10 leucocytes per ml. of unspun urine, was seen on this first occasion in 12 children $(60 \%)$, whereas numerous bacteria were visible in every specimen.

\section{Bacteriological and Radiological Studies}

Escherichia coli was cultured in 18 cases, Streptococcus faecalis in one case, and Proteus species of bacillus in one.

The individual radiological findings are shown in Table II and are summarized in Table IV. Only four children $(20 \%)$

$$
\begin{aligned}
& \text { TABLE IV.-Radiological Studies in } 20 \text { Children with Asymptomatic } \\
& \text { Intravenous pyelogram: } \\
& \begin{array}{llllllll}
\text { Abnormal } & \text { Pyelonephritis } & \ldots & \ldots & \ldots & \ldots & \ldots & \ldots
\end{array} \\
& \begin{array}{lllll}
\text { Dilated ureter and/or pelves and calices } & \ldots & \ldots & \ldots & 3 \\
\text { Duplication of upper urinary tract } & \ldots & \ldots & \ldots & 2
\end{array}
\end{aligned}
$$

8
3
6
2
4
8
4

had a normal I.V.P. and cystogram. Three children had unequivocal evidence of pyelonephritis, and in two cases this was bilateral. Possibly this is a minimal figure, for slight scarring of the renal cortex in other children may have been missed, as tomograms during pyelography were not routinely used until the latter part of the survey. The radiological diagnosis of pyelonephritis followed the criteria reported by Hodson (1959). Fourteen children ( $70 \%$ ) had an abnormal cystogram, and in $8(40 \%)$ there was vesicoureteric reflux. A "spinning 
top" urethra was seen in seven children, and this was not always associated with a radiological abnormality.

\section{Cystoscopy}

In this age group a 24 French bougie à boule should pass into the urethra without difficulty; however, in 8 of the 10 children in whom cystoscopy was carried out a distal urethral constriction was found with a calibre of 14-16 French.

\section{Clinical and Radiological Findings}

The numbers were too small to be statistically assessed. Nevertheless, an abnormal intravenous pyelogram was probably more commonly found when there was either a history of no dry period, a past history of infection, or a height and weight less than the 25 th percentile. It was also more common to find reflux in children whose height and weight were below the 25 th percentile.

\section{Spontaneous or Antibiotic Cure}

In one girl in whose urine confluent growth of $E$. coli on the first specimen and $100,000 E$. coli on the second specimen were found, and in another whose first specimen had semiconfluent growth of $E$. coli and the second 100,000 E. coli there was a definite history of urgency and frequency of micturition during the period in which the urine specimens had been obtained. In the first case no antibiotic had been given and the symptoms settled after three weeks; this child was investigated and found to have a normal intravenous pyelogram and micturating cystogram. The other child had had a temperature for which she received a course of ampicillin from her general practitioner, followed later by a course of tetracycline, when she had remained unwell. It is interesting that in this child the $E$. coli isolated from the first urine specimen was resistant to ampicillin. Both children have been followed up and their urine has remained sterile. Five children with a single urine specimen with confluent growth had been generally unwell when this specimen of urine had been examined, and two had required antibiotics from their general practitioners. None had had symptoms of lower urinary tract infection. Because they had been unwell, one or two weeks often elapsed between examination of the first and second specimens of urine. All these children's specimens were sterile on the second and third examination.

\section{Discussion}

Unlike Kunin et al. (1964), we did not wash the girls' external genitals nor did we spread their labia before micturition. This simplified the collections for both nurse and child. It has also been shown that the use of antiseptic cleaning solutions may give rise to false-negatives (Roberts et al., 1967). In Kunin's series $2.4 \%$ of the initial cultures showed more than 100,000 viable bacteria per $\mathrm{ml}$. of urine, which is comparable to the $3.9 \%$ of urine specimens with confluent or semiconfluent growth which we have found. Kunin suggested that under field conditions a count of 100,000 viable bacteria per ml. of urine is significant in about half the cases. In this study, despite the absence of cleansing techniques, $48.6 \%$ of the children with confluent or semiconfluent growth in the initial urine specimen were confirmed as having a urinary infection. Certainly in these young girls contamination of the urine is not a serious problem with our method of urine collection.

Our prevalence of $2 \cdot 1 \%$ is greater than Kunin's overall figure of $1.1 \%$ and the $1.5 \%$ which he found in his youngest group of white girls aged 6-7 years. Like Kunin, we consider our prevalence rate to be a minimum figure, for the number of falsenegatives in our series is unknown. It does appear, however, that a significant number of young girls in the community have undetected urinary infection, for only two of our cases were under surveillance at the time, and, though three others were known to have had infection in the past, the parents did not recognize its continuing nature. In 15 children (75\%) there was no history of past urinary infection, a percentage similar to that found by Kunin.

The children with apparent spontaneous or antibiotic cure of possible urinary infection are difficult to evaluate. They are not included as definite cases of urinary infection as they did not have persistent bacteriuria. They are mentioned only because in two of the children there were transient lower urinary tract symptoms, and in the remainder there was a history of being unwell the day their urine was examined.

Kunin found that $43.5 \%$ of 5-9-year-old white girls with asymptomatic bacteriuria had symptoms of urinary infection. In our series $70 \%$ of the children had symptoms referable to the lower urinary tract. Nocturnal enuresis was often present, and in many cases the child had never been dry at night. Many children had such urgency that they regularly wet their pants before they could reach the lavatory, and frequency of micturition, 6 to 10 times daily, was very common. In most cases it appeared that these symptoms had persisted for so long that the parents accepted them as normal, and merely a nuisance which the child would eventually outgrow. Yet in most cases they were so striking that had the parents been directly questioned the physician would have been alerted to examine the urine. That only one mother thought her child to be in other than good health reflects the casual attitude generally taken to symptoms of lower urinary tract infection in childhood, and it is unfortunate that the natural pattern, from bed-wetting and daytime accidents to full bladder control, mimics these symptoms.

That only $60 \%$ of these children had pyuria was not unexpected in view of Kunin's findings. He found pyuria in $44.3 \%$ of his cases, and in an earlier report only 1 out of 15 girls with urinary infection had white blood cells in excess of 4 per high-power field in the initiai catheter urine specimen. It is often held that pyuria is the hallmark of urinary infections ; but it is apparent, from both Kunin's and our figures, that this fact does not hold for cases detected during screening programmes ; indeed, if we had used this as our criterion in screening for urinary infection we would have missed nearly half the cases. There was no correlation between the presence of pyuria and the incidence of urological abnormalities, a fact which Kunin also noted in his survey.

Though only a few children were cystoscoped several had distal urethral stenosis; possibly this may be a factor in perpetuating the infection.

Many of our children had abnormal radiological findings, and compared with Kunin's white girls aged 5-9 years the incidence of abnormalities is very similar. Calicectasis in $12 \cdot 1 \%$ was the commonest abnormality that Kunin found on intravenous pyelography, and reflux in $33.3 \%$ the most frequent on cystographic study. This compared with the $15 \%$ with pyelonephritis and $40 \%$ with reflux in our cases. In some children minor degrees of pyelonephritic scarring may have been missed, while the earliest changes of pyelonephritis are in any case not visible radiologically. Similarly, reflux may be intermittent and a negative cystogram does not exclude its presence (Hutch et al., 1963). It is for these reasons that we assume our figures for the incidence of pyelonephritis and vesicoureteric reflux to be conservative.

The importance of these findings is the presence of bacteriuria in association with vesicoureteric reflux in a group of children previously unknown to have urinary infection and possibly unlikely to have been detected except by screening. Reflux does not occur in the normal urinary tract except 
perhaps in the neonatal period (Hodson, 1967). Its coexistence with bacteriuria does not necessarily imply that the bacteria are the primary cause of the lesion, for it has been amply shown that congenital abnormality renders the renal tract more susceptible to bacterial invasion. The important fact is that progressive disease of renal tissue leading to azotaemia occurs readily in the presence of proliferating bacteria (Cotran, 1965). Vesicoureteric reflux will allow this to occur by acting as a reservoir for continuing infection and by directly conveying the infected urine to the kidneys. Though the exact role of reflux in the production of pyelonephritis remains obscure it is certainly of considerable importance in determining the prognosis of children with urinary infection (Williams, 1965). The fact that in our cases we performed the cystograms while the urines were infected does not invalidate the seriousness of these findings.

Many people believe that the small scarred kidney of adult life may arise after recurrent urinary infection in early childhood (Smellie et al., 1964 ; Rosenheim, 1965). It is immaterial that in many cases there is no past history of urinary infection, for in infants and young children urinary infection often presents in atypical fashion, and in the past must frequently have been undiagnosed (Stansfeld, 1954); in addition, even when associated with advanced renal changes, it may be asymptomatic (Kunin et al., 1962). This group of children amply illustrates these points. Undiagnosed or misdiagnosed, symptomatic but unrecognized, or genuinely asymptomatic, they may include a number who are relentlessly progressing to chronic pyelonephritis. In later life they would have been unaware of the chronic urinary infection which they had had during their childhood years.

The small stature of many of the children was an unexpected finding. None was $2,500 \mathrm{~g}$. or less at birth, but the mothers of six of the children were under $5 \mathrm{ft} .(152 \mathrm{~cm}$.) in height. It is possible that the small stature of these children was wholly or in part genetically determined. Growth retardation in the presence of appreciable chronic disease is well recognized, but it seems unlikely that it would have occurred in the presence of a low-grade bladder infection. It is therefore interesting to observe the apparent association of reflux or an abnormal intravenous pyelogram in children with a height and weight under the 25 th percentile. Certainly their small stature, if due to their bacteriuria, suggests the infection is of comparatively long standing and of some significance. With a larger series of children it is hoped that this aspect of asymptomatic bacteriuria will be better defined.

In treating these children our experience has confirmed Kunin's finding that children with asymptomatic bacteriuria are highly susceptible to reinfection, and that it is often difficult to sterilize their urine for any length of time. By the very chronicity of their disease they may therefore have a poorer prognosis than children with overt disease. It is, however, only by long-term prospective studies on such groups of children that this will be determined.

We set out in this survey to test the ease with which uncontaminated urine specimens could be collected, and to define the prevalence of urinary infection in young girls entering primary school. Both these objects have been satisfactorily determined. In our series we found that a large percentage of the children with asymptomatic bacteriuria had symptoms of lower urinary tract infection; continuing work here, however, indicates that the proportion of children with genuinely asymptomatic infection is higher than our present figure would suggest. The question therefore arises whether screening for asymptomatic bacteriuria in children should be generally recommended. Much circumstantial data suggest that it should; however, it would be unwise to advocate such screening on a large scale when the natural history of the condition is still unknown. Wilson and Jungner (1968) discussed the criteria to be met before any screening programme of chronic non- communicable disease can be generally recommended. When these are applied to asymptomatic bacteriuria in childhood a number of the principles cannot at present be satisfied. It is not known, for example, whether the condition is an important health problem, and its long-term significance, especially in its relation to chronic pyelonephritis, is unknown. Furthermore, there cannot at present be an agreed policy on whom to treat as patients.

We think, therefore, that national screening for and treatment of asymptomatic bacteriuria in children cannot as yet be recommended on a scientific basis. What is required are wellplanned surveys, with randomized trials of intervention by treatment, for only by this means can the effect of treatment be properly judged and the relation of the condition to chronic pyelonephritis be accurately assessed. Nevertheless, there is a need for greater awareness of the symptomatology of overt urinary tract infection in childhood. School medical officers examine all school entrants, and children with a past history of urinary infection, or a history suggesting it, should have their urine examined.

It is a pleasure to thank many colleagues for their helpful discussion during this survey. We wish to thank Professor J. L. Henderson, Professor J. P. Duguid, and Professor A. Mair for their advice and encouragement. To Dr. I. B. L. Weir, the school medical officers, health visitors, and school nurses of Dundee Child Health Services we are especially grateful, for this study would not have been possible without their help and co-operation. We thank Mr. S. B. Oram, child health services administrative assistant, and Miss I Shiel, superintendent health visitor, for their help throughout the survey ; Dr. Constance Forsyth and the staff of the paediatric ward at Maryfield Hospital, where the special investigations were carried out; Dr. D. Dewar for the radiological studies; Mr. J. Grieve for the cystoscopic findings; Mr. J. Pearson for statistical analysis of the figures; Mrs. B. Forsyth and Mrs. A. Hutchison for secretarial help ; and Mr. R. Fawkes for photography. One of us (D. C. L. S.) is in receipt of a grant for this survey from the Board of Management for Dundee General Hospitals, and we are grateful to them.

\section{REFERENCES}

Bradley, J. M., Crowley, N., and Darrell, J. H. (1967). British Medical fournal, 4, 649.

Cotran, R. S. (1965). Progress in Pyelonephritis, edited by E. H. Kass, p. 371. Philadelphia, Davis.

Freedman, L. R., Phair, J. P., Seki, M., Hamilton, H. B., Nefzger, cine, $37,262$.

Hodson, C. J. (1959). Proceedings of the Royal Society of Medicine, $52,669$.

Hodson, C. J. (1967). In Renal Disease, edited by D. A. K. Black, 2nd ed., p. 157. Oxford, Blackwell.

Hutch, J. A., Miller, E. R., and Hinman, F. (1963). American fournal of Medicine, 34, 338.

Kunin, C. M. (1966). Annual Review of Medicine, 17, 383.

Kunin, C. M., Deutscher, R., and Paquin, A. J. (1964). Medicine, 43, 91.

Kunin, C. M., Zacha, E., and Paquin, A. J. (1962). New England Fournal of Medicine, 25, 1287.

Miall, W. E., Kass, E. H., Ling, J., and Stuart, K. L. (1962). British Medical fournal, 2, 497.

Roberts, A. P., Robinson, R. E., and Beard, R. W. (1967). British Medical fournal, 1, 400.

Rosenheim, M. L. (1965). Progress in Ryelonephritis, edited by E. H. Kass, p. 369. Philadelphia, Davis.

Smellie, J. M., Hodson, C. J., Edwards, D., and Normand, I. C. S. (1964). British Medical fournal, 2, 1222.

Stansfeld, J. M. (1954). Proceedings of the Royal Society of Medicine, 47, 631 .

Urquhart, G. E. D., and Gould, J. C. (1965). Fournal of Clinical Patho$\log y, 18,480$.

Williams, D. I. (1965). Lancet, 1, 109.

Wilson, J. M. G., and Jungner, C. (1968). Principles and Practice of Screening for Disease. Geneva, W.H.O.

Winberg, J. (1967). Acta Paediatrica Scandinavica, Suppl. No. 177, p. 42 . 